[Chem. Pharm. Bull.

36( 9$) 3348-3353(1988)]$

\title{
Quinolizidines. XXV." An Extension of the "Lactim Ether Route" to the Racemic Syntheses of Several Indolo[2,3-a]quinolizidine Alkaloids
}

\author{
Tozo Fujil,* Shigeyuki Yoshifuji, and Harue Ito \\ Faculty of Pharmaceutical Sciences, Kanazawa University, \\ Takara-machi, Kanazawa 920, Japan
}

(Received March 9, 1988)

\begin{abstract}
The "lactim ether route," originally designed for unified racemic and chiral syntheses of the benzo[a]quinolizidine-type Alangium alkaloids, has been extended to cover the racemic syntheses of several indolo[2,3-a]quinolizidine alkaloids $(\mathbf{1}$ and $\mathbf{8 c}, \mathbf{d})$. The synthetic routes started from the lactams $\mathbf{5 a}, \mathbf{b}$ and proceeded smoothly through the lactim ethers $\mathbf{6 a}, \mathbf{b}$, lactam ketones $\mathbf{7 a}, \mathbf{b}$, lactam alcohols 10a, b, and $N$-substituted lactams $9 \mathbf{a}, \mathbf{b}$.
\end{abstract}

Keywords_-indoloquinolizidine alkaloid synthesis; Corynanthe alkaloid; $N$-substituted lactam; lactim ether alkylation; sodium borohydride reduction; catalytic hydrogenolysis; BischlerNapieralski cyclization

The indole alkaloids, a large and complex group of natural products bearing the indole or 2,3-dihydroindole (indoline) ring in their structures, include a number of indolo[2,3-a]quinolizidine alkaloids (e.g., 1), often referred to as indoloquinolizidine alkaloids. ${ }^{2}$ Although the chemical structures of most of the known indoloquinolizidine alkaloids have been unequivocally established, there are some structural problems still remaining even in this new era of highly refined spectroscopic studies. ${ }^{2 c)}$ Solutions to these problems could come with the racemic and/or chiral syntheses of compounds possessing the candidate structures, and the syntheses might be feasible through the "lactim ether route", 3 ) which has proved

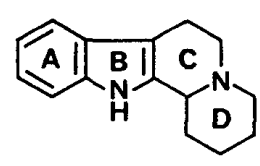

1

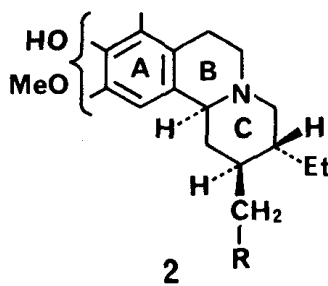

2

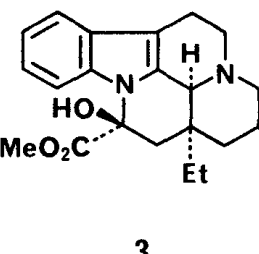

3<smiles></smiles>

4

useful and effective for the racemic and chiral syntheses of the structurally analogous benzo[ $a$ ]quinolizidine-type Alangium alkaloids (type 2 ) ${ }^{3 d, 4)}$ In the present work, the feasibility of such a synthetic approach was tested in the racemic syntheses of several of the known indoloquinolizidine alkaloids, such as $\mathbf{1}$ and $\mathbf{8 c}, \mathbf{d .}{ }^{5)}$

Alkylation of the lactim ether $\mathbf{6 a}$, obtained in $84 \%$ yield from the unsubstituted lactam $5 \mathbf{a}$ according to the literature procedure, ${ }^{3 a, 6)}$ with 3-(chloroacetyl)indole in $\mathrm{HCONMe}_{2}$ at $60^{\circ} \mathrm{C}$ in the presence of $\mathrm{KBr}$ for $24 \mathrm{~h}$ furnished the lactam ketone $7 \mathrm{a}$ in $71 \%$ yield. In the absence of $\mathrm{KBr}$, the progress of alkylation was extremely slow, suggesting the intermediary formation of 3-(bromoacetyl)indole in the above alkylation. Reduction of 7a with $\mathrm{NaBH}_{4}$ in aqueous EtOH at room temperature for $20 \mathrm{~h}$ gave the lactam alcohol 10a $(96 \%$ yield), which was then hydrogenolyzed $\left(10 \% \mathrm{Pd}-\mathrm{C} / \mathrm{H}_{2}, 20{ }^{\circ} \mathrm{C}, 1 \mathrm{~atm}, 50 \mathrm{~min}\right)$ in $\mathrm{EtOH}$ containing a small amount of 

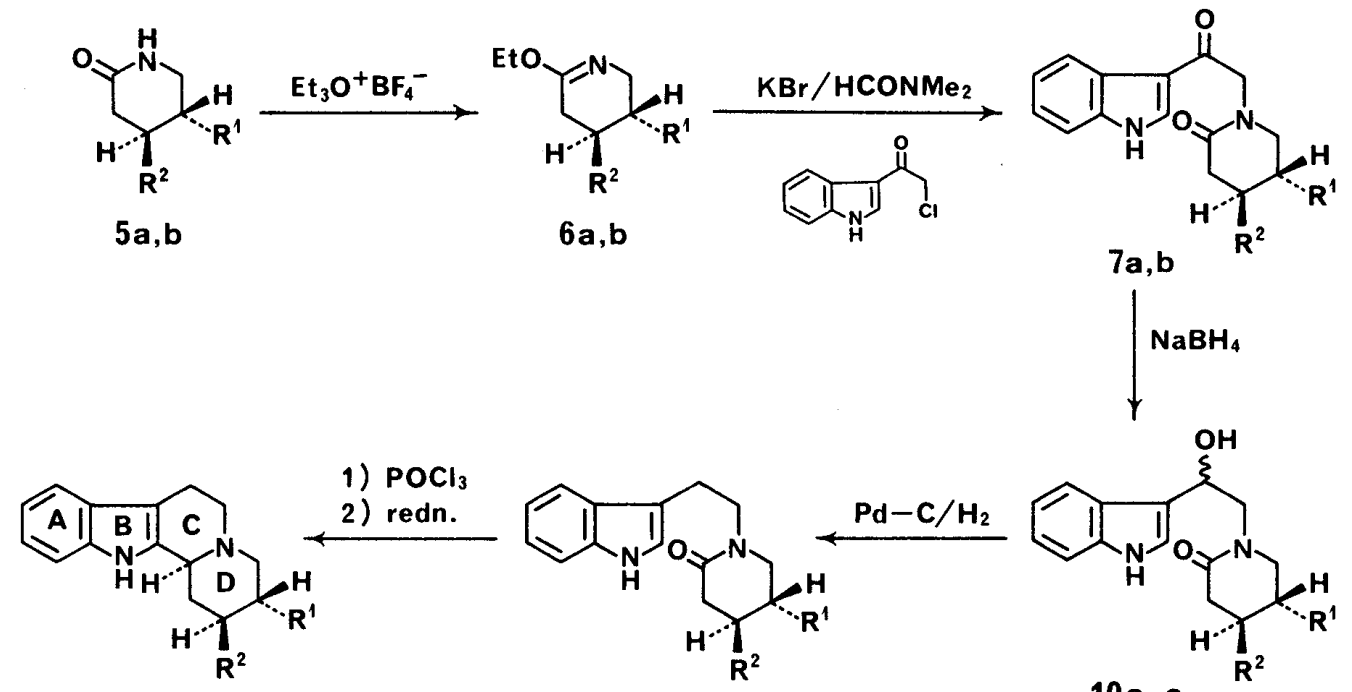<smiles>[R17]CCCCc1c[nH]c2ccccc12</smiles><smiles>[R]C1C(=O)N(C[C@H](O)c2c[nH]c3ccccc23)C[C@@H]([R2])[C@H]1[R2]</smiles>
1: $R^{1}=R^{2}=H$ 8 b-e<smiles>CCCN1CCCCC1=O</smiles>

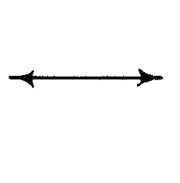<smiles>CCCCN1CCCCC1=O</smiles>

12<smiles>CCOC(=O)c1[nH]c2ccccc2c1CC(CN1CCCCC1=O)OCC</smiles>

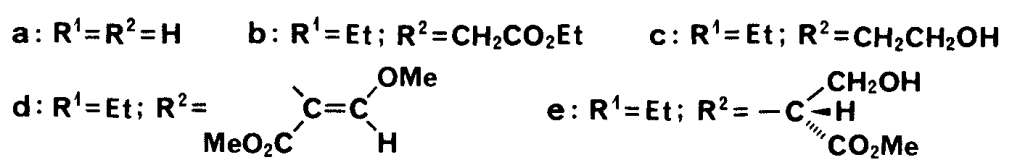

Chart 1

$70 \%$ aqueous $\mathrm{HClO}_{4}$ to afford the known lactam $9 \mathrm{a}^{7)}$ in $96 \%$ yield. The hydroxy group of $10 \mathrm{a}$ at the indolylcarbinyl carbon was found to be considerably reactive. On treatment with EtOH in the presence of a catalytic amount of $\mathrm{HCl}$ at $25^{\circ} \mathrm{C}$ for $1 \mathrm{~h}, 10 \mathrm{a}$ produced the ethoxy derivative 13 in $94 \%$ yield. Conversely, treatment of 13 with $\mathrm{H}_{2} \mathrm{O}$ in $\mathrm{MeCN}$ containing a catalytic amount of $\mathrm{HCl}$ at $17^{\circ} \mathrm{C}$ for $1 \mathrm{~h}$ reproduced the lactam alcohol 10a in $86 \%$ yield. These transformations reflect the acid-catalyzed formation of the reactive "3-indolylcarbinyl system" ${ }^{8)}(\mathbf{1 1} \leftrightarrow \mathbf{1 2})$ from 10a and from 13. Catalytic hydrogenolysis of 13 to give $9 \mathrm{a}$ was smoothly effected under reaction conditions similar to those employed for the above conversion of 10a into 9a, but the result was less satisfactory when the reaction was carried out in the absence of $\mathrm{HClO}_{4}$.

Bischler-Napieralski cyclization of the lactam $9 \mathrm{a}\left(\mathrm{POCl}_{3} \text {, boiling benzene, } 75 \mathrm{~min}\right)^{7)}$ and reduction of the resulting quaternary salt $\left(\mathrm{NaBH}_{4}, \mathrm{MeOH}, 1 \mathrm{~h}\right)^{7)}$ provided the tetracyclic base $1(95 \%$ overall yield from $9 a)$, which was identical with an authentic sample. $\left.{ }^{7}\right)$ The tetracycle 1 is the simplest member of the indoloquinolizidine alkaloids: Its ( - )-isomer, yet unnamed, has been isolated ${ }^{\text {9) }}$ in partially racemized form from the leaves of a New Guinea tree, Dracontomelum mangiferum BL., belonging to the family Anacardiaceae. Although more than 30 synthetic routes to this parent framework (1) have been reported, ${ }^{7,10)}$ our "lactim ether route" described above may be of value, not only in preparing the alkaloid material (1) in an 
acceptable overall yield but also in the design and execution of the total syntheses of analogous alkaloids carrying substituents in ring $\mathrm{A}$ and/or ring $\mathrm{D}$.

In order to evaluate the applicability of the "lactim ether route" to synthesis of more complex indoloquinolizidine alkaloids, we next tried to synthesize $( \pm)$-dihydrocorynantheine $(\mathbf{8 d})$ and related alkaloids from the $( \pm)$-trans-lactam ester $\mathbf{5 b}$. The starting material $\mathbf{5} \mathbf{b}^{11)}$ was first converted into the lactim ether $\mathbf{6 b}$ in excellent yield by an ethylation method given in the literature. ${ }^{12)}$ Treatment of $\mathbf{6 b}$ with 3-(chloroacetyl)indole in $\mathrm{HCONMe}_{2}$ at $60^{\circ} \mathrm{C}$ in the presence of $\mathrm{KBr}$ for $38 \mathrm{~h}$ gave the lactam ketone $7 \mathbf{b}$ in $70 \%$ yield. Reduction of $7 \mathbf{b}$ with $\mathrm{NaBH}_{4}$ $\left(\mathrm{EtOH}, 22-25^{\circ} \mathrm{C}, 3 \mathrm{~h}\right)$ furnished a diastereomeric mixture of the lactam alcohol $10 \mathrm{~b}$ in $70 \%$ yield. Prolonged reduction in this case was found to lower the yield of $10 \mathrm{~b}$ owing to the formation of a by-product presumed to be a diastereomeric mixture of the diol 10c. The diastereomeric mixture $10 \mathrm{~b}$ was then submitted to hydrogenolysis $\left(10 \% \mathrm{Pd}-\mathrm{C} / \mathrm{H}_{2}, \mathrm{EtOH}\right.$, $1 \mathrm{~atm}, 21-22{ }^{\circ} \mathrm{C}, 1 \mathrm{~h}$ ) in the presence of a small amount of $70 \%$ aqueous $\mathrm{HClO}_{4}$ to afford the $( \pm)$-trans-lactam ester $\mathbf{9 b}\left(74 \%\right.$ yield), which was identical with an authentic sample. ${ }^{13)}$ The lactam ester $\mathbf{9 b}$ has been converted into $( \pm)$-dihydrocorynantheine $(\mathbf{8 d})^{13,14)}$ and $( \pm)$ dihydrocorynantheol $(\mathbf{8 c})^{15)}$ through the $( \pm)$-tetracyclic ester $\mathbf{8 b ^ { 1 3 ) }}$ (and $(+)$-dihydrocorynantheine $[(+)-\mathbf{8 d}]$ has been shown to lead to $(-)$-dihydrositsirikine $\left.[(+)-8 \mathbf{e}]^{16)}\right)$. Consequently, the above results $(\mathbf{5 b} \rightarrow \mathbf{6 b} \rightarrow \mathbf{7 b} \rightarrow \mathbf{1 0 b} \rightarrow \mathbf{9 b})$ imply that an alternative synthesis of each of these alkaloids has now been completed in a formal sense.

In summary, the scope of our "lactim ether route", ${ }^{3)}$ originally designed for unified racemic and chiral syntheses of the benzo[a]quinolizidine-type Alangium alkaloids, ${ }^{\left.3{ }^{3,4}\right)}$ has now been enlarged to include the syntheses of the indoloquinolizidine-type analogues. Interestingly, after the disclosure ${ }^{5)}$ of a summary of the present work, Govindachari's group has reported that this route was also effective for the synthesis of $( \pm)$-vincamine $(3) .{ }^{17)}$ Other successful applications in the Corynanthe-type indoloquinolizidine series are seen in our recent racemic and chiral syntheses of ochropposinine $(4),{ }^{18)}$ which unequivocally established the structure and absolute stereochemistry of this Ochrosia alkaloid.

\section{Experimental}

General Notes_-All melting points were determined by using a Yamato MP-1 capillary melting point. apparatus and are corrected. Unless otherwise noted, the organic solutions obtained after extraction were dried over anhydrous $\mathrm{Na}_{2} \mathrm{SO}_{4}$ and concentrated under reduced pressure. Spectra reported herein were recorded on a Hitachi 323 ultraviolet (UV) spectrophotometer, a JASCO IRA-2 infrared (IR) spectrophotometer, a JEOL JMS-01SG mass spectrometer, or a JEOL JNM-PS-100 nuclear magnetic resonance (NMR) spectrometer at $23^{\circ} \mathrm{C}$ with $\mathrm{Me}_{4} \mathrm{Si}$ as an internal standard. Elemental analyses were performed by Mr. Y. Itatani and his associates at Kanazawa University. The following abbreviations are used: $\mathrm{br}=$ broad, $\mathrm{m}=$ multiplet, $\mathrm{q}=$ quartet, $\mathrm{s}=$ singlet, $\mathrm{sh}=$ shoulder, $\mathrm{t}=$ triplet.

1-[2-(1 H-Indol-3-yl)-2-oxoethyl]-2-piperidinone (7a)—A solution of $\mathbf{6 a}^{3 a, 6)}(12.59 \mathrm{~g}, 99 \mathrm{mmol})$ and 3-(chloroacetyl)indole $\left.{ }^{19}\right)(17.40 \mathrm{~g}, 90 \mathrm{mmol})$ in $\mathrm{HCONMe}_{2}(20 \mathrm{ml})$ containing $\mathrm{KBr}(12.85 \mathrm{~g}, 108 \mathrm{mmol})$ was stirred at $60^{\circ} \mathrm{C}$ for $24 \mathrm{~h}$. After cooling, the reaction mixture was poured into a mixture of $\mathrm{H}_{2} \mathrm{O}(400 \mathrm{ml})$ and AcOEt $(100 \mathrm{ml})$. The precipitate that resulted was filtered off, washed successively with $\mathrm{H}_{2} \mathrm{O}(100 \mathrm{ml})$ and AcOEt $(80 \mathrm{ml})$, and dried to give $7 \mathrm{a}(13.44 \mathrm{~g})$ as a brown powder, $\mathrm{mp} 235.5-236.5^{\circ} \mathrm{C}$. The AcOEt layer separated from the filtrate was washed with $\mathrm{H}_{2} \mathrm{O}(150 \mathrm{ml})$, dried, and concentrated to leave a brown oil. The oil was triturated with $\mathrm{MeCN}(80 \mathrm{ml})$, and the insoluble solid that resulted was collected by filtration and dried to yield a second crop $(2.97 \mathrm{~g})$ of $7 \mathrm{a}, \mathrm{mp} 235-236^{\circ} \mathrm{C}$. The total yield was $16.41 \mathrm{~g}$ [71\% yield based on the 3-(chloroacetyl)indole used]. Recrystallization of the solid from MeCN gave an analytical sample as colorless pillars, mp 240-241 ${ }^{\circ} \mathrm{C} ; \mathrm{MS} m / z: 256\left(\mathrm{M}^{+}\right)$; UV $\lambda_{\text {max }}^{\mathrm{EtOH}} 242 \mathrm{~nm}(\varepsilon 13200)$, 260 (sh) (9000), 299 (12800); IR $v_{\max }^{\mathrm{Nujol}} \mathrm{cm}^{-1}: 3120,3080(\mathrm{NH}), 1648$ (ArCO), 1607 (lactam CO); NMR $\left(\mathrm{Me}_{2} \mathrm{SO}-d_{6}\right) \delta:$ $1.48-1.88\left(4 \mathrm{H}, \mathrm{m}, \mathrm{H}_{(4)}\right.$ 's and $\mathrm{H}_{(5)}$ 's), 2.06-2.40 (2H, m, $\mathrm{H}_{(3)}$ 's), 3.10-3.40 (2H, m, $\mathrm{H}_{(6)}$ 's $), 4.60\left(2 \mathrm{H}, \mathrm{s}, \mathrm{COCH}_{2} \mathrm{~N}\right)$, $6.94-8.32\left(5 \mathrm{H}, \mathrm{m}\right.$, aromatic protons), $11.80(1 \mathrm{H}$, br s, $\mathrm{NH})$. Anal. Calcd for $\mathrm{C}_{15} \mathrm{H}_{16} \mathrm{~N}_{2} \mathrm{O}_{2}: \mathrm{C}, 70.29 ; \mathrm{H}, 6.29 ; \mathrm{N}, 10.93$. Found: C, 70.15; H, 6.28; N, 10.83 .

1-[2-Hydroxy-2-(1 H-indol-3-yl)ethyl]-2-piperidinone (10a)- - i) By Reduction of 7a: A solution of 7a (500 mg, $1.95 \mathrm{mmol})$ in $80 \%(\mathrm{v} / \mathrm{v})$ aqueous $\mathrm{EtOH}(50 \mathrm{ml})$ was stirred under ice-cooling, and $\mathrm{NaBH}_{4}(370 \mathrm{mg}, 9.76 \mathrm{mmol})$ was added portionwise. After the mixture had been stirred at $14-20^{\circ} \mathrm{C}$ for $20 \mathrm{~h}$, acetone $(3 \mathrm{ml})$ was added under icecooling. The resulting mixture was further stirred for $10 \mathrm{~min}$ and then concentrated in vacuo. The residue was treated 
with $\mathrm{H}_{2} \mathrm{O}(20 \mathrm{ml})$, and the aqueous mixture was neutralized with $10 \%$ aqueous $\mathrm{HCl}$. The precipitate that resulted was filtered off, washed with $\mathrm{H}_{2} \mathrm{O}$, and dried to give $10 \mathrm{a}(490 \mathrm{mg}, 96 \%)$ as a colorless powder, $\mathrm{mp} 177-179^{\circ} \mathrm{C}$. Recrystallization from EtOH produced an analytical sample as colorless prisms, $\mathrm{mp} 178-179^{\circ} \mathrm{C} ; \mathrm{MS} \mathrm{m} / z: 258\left(\mathrm{M}^{+}\right)$; $\mathrm{UV} \lambda_{\max }^{\mathrm{EtOH}} 274 \mathrm{~nm}(\mathrm{sh})(\varepsilon 5850), 282(6300), 290(5500) ; \mathrm{IR} v_{\max }^{\mathrm{Nujol}} \mathrm{cm}^{-1}: 3200(\mathrm{NH}$ and OH), 1600 (lactam CO); NMR $\left(\mathrm{Me}_{2} \mathrm{SO}-d_{6}\right) \delta: 1.32-1.84\left(4 \mathrm{H}, \mathrm{m}, \mathrm{H}_{(4)}\right.$ 's and $\mathrm{H}_{(5)}$ 's), $2.08-2.40\left(2 \mathrm{H}, \mathrm{H}_{(3)}\right.$ 's), 2.84-3.84 [4H, m, $\mathrm{H}_{(6)}$ 's and $\left.\mathrm{CH}(\mathrm{OH}) \mathrm{CH}_{2} \mathrm{~N}\right], 4.92-5.36\left[2 \mathrm{H}, \mathrm{m}, \mathrm{CH}(\mathrm{OH}) \mathrm{CH}_{2} \mathrm{~N}\right], 6.80-7.76(5 \mathrm{H}, \mathrm{m}$, aromatic protons $), 10.56(1 \mathrm{H}, \mathrm{br}, \mathrm{NH})$ Anal. Calcd for $\mathrm{C}_{15} \mathrm{H}_{18} \mathrm{~N}_{2} \mathrm{O}_{2}$ : C, 69.75; H, 7.02; N, 10.84. Found: C, 69.48; H, 7.01; N, 10.86 .

ii) By Hydrolysis of 13: A solution of $13(258 \mathrm{mg}, 0.9 \mathrm{mmol})$ in $50 \%(\mathrm{v} / \mathrm{v})$ aqueous $\mathrm{MeCN}(7 \mathrm{ml})$ containing $0.02 \mathrm{~N}$ aqueous $\mathrm{HCl}(2 \mathrm{ml})$ was stirred at $17^{\circ} \mathrm{C}$ for $1 \mathrm{~h}$. After addition of $10 \%$ aqueous $\mathrm{Na}_{2} \mathrm{CO}_{3}(1 \mathrm{ml})$, the reaction mixture was concentrated in vacuo to a small volume, and the residue was extracted with $\mathrm{CHCl}_{3}$. $\mathrm{The}_{\mathrm{CHCl}}$ extracts were washed with $\mathrm{H}_{2} \mathrm{O}$, dried, and concentrated to leave $10 \mathrm{a}(200 \mathrm{mg}, 86 \%)$ as colorless prisms, $\mathrm{mp} 174-177^{\circ} \mathrm{C}$. This sample was identical [by comparison of the IR spectrum and thin-layer chromatographic (TLC) mobility] with the one described above under item (i).

1-[2-Ethoxy-2-(1 H-indol-3-yl)ethyl]-2-piperidinone (13)-A solution of 10a (258 $\mathrm{mg}, 1 \mathrm{mmol})$ in abs. EtOH $(40 \mathrm{ml})$ containing $0.02 \mathrm{~N}$ aqueous $\mathrm{HCl}(2.1 \mathrm{ml})$ was stirred at $25^{\circ} \mathrm{C}$ for $1 \mathrm{~h}$. After addition of $10 \%$ aqueous $\mathrm{Na}_{2} \mathrm{CO}_{3}$ ( $1 \mathrm{ml})$, the reaction mixture was concentrated in vacuo. The residue was dissolved in $\mathrm{CH}_{2} \mathrm{Cl}_{2}(25 \mathrm{ml})$, and the $\mathrm{CH}_{2} \mathrm{Cl}_{2}$ solution was washed with $\mathrm{H}_{2} \mathrm{O}$, dried, and concentrated to leave $13(270 \mathrm{mg}, 94 \%)$ as yellowish crystals, $\mathrm{mp} 137-$ $138^{\circ} \mathrm{C}$. Recrystallization from MeCN yielded an analytical sample as colorless prisms, $\mathrm{mp} 138-139^{\circ} \mathrm{C} ; \mathrm{MS} m / z: 286$ $\left(\mathrm{M}^{+}\right)$; UV $\lambda_{\max }^{\mathrm{EtOH}} 274 \mathrm{~nm}(\varepsilon 6100), 282(6400), 290(5700) ; \mathrm{IR} v_{\max }^{\mathrm{Nujol}} \mathrm{cm}^{-1}: 3320(\mathrm{NH}), 1627$ (lactam CO); NMR $\left(\mathrm{CDCl}_{3}\right) \delta: 1.13\left(3 \mathrm{H}, \mathrm{t}, J=7 \mathrm{~Hz}, \mathrm{OCH}_{2} \mathrm{Me}\right), 1.45-1.90\left(4 \mathrm{H}, \mathrm{m}, \mathrm{H}_{(4)}\right.$ 's and $\mathrm{H}_{(5)}$ 's $), 2.20-2.55\left(2 \mathrm{H}, \mathrm{m}, \mathrm{H}_{(3)}\right.$ 's $), 2.85-$ $4.00\left[6 \mathrm{H}, \mathrm{m}, \mathrm{H}_{(6)}\right.$ 's, $\mathrm{CH}(\mathrm{OEt}) \mathrm{C}_{2} \mathrm{~N}$, and $\left.\mathrm{OCH}_{2} \mathrm{Me}\right], 4.85-5.06\left[1 \mathrm{H}, \mathrm{m}, \mathrm{C} \underline{\mathrm{H}}(\mathrm{OEt}) \mathrm{CH}_{2} \mathrm{~N}\right], 6.88-7.88(5 \mathrm{H}, \mathrm{m}$, aromatic protons), $9.09\left(1 \mathrm{H}\right.$, br s, NH). Anal. Calcd for $\mathrm{C}_{17} \mathrm{H}_{22} \mathrm{~N}_{2} \mathrm{O}_{2}: \mathrm{C}, 71.30 ; \mathrm{H}, 7.74 ; \mathrm{N}, 9.78$. Found: C, 71.29; $\mathrm{H}$, $7.87 ; \mathrm{N}, 9.87$.

1-[2-(1 H-Indol-3-yl)ethyl]-2-piperidinone (9a)_-i) From 10a: A solution of 10a $(517 \mathrm{mg}, 2 \mathrm{mmol})$ in EtOH $(100 \mathrm{ml})$ containing $70 \%$ aqueous $\mathrm{HClO}_{4}(0.02 \mathrm{ml}$, ca. $0.2 \mathrm{mmol})$ was hydrogenated over $10 \% \mathrm{Pd}-\mathrm{C}(400 \mathrm{mg})$ at $20^{\circ} \mathrm{C}$ and atmospheric pressure for $50 \mathrm{~min}$. The catalyst was removed by filtration, and the filtrate, after addition of $10 \%$ aqueous $\mathrm{Na}_{2} \mathrm{CO}_{3}(1 \mathrm{ml})$, was concentrated in vacuo. The residue was partitioned by extraction with a mixture of $\mathrm{H}_{2} \mathrm{O}$ $(10 \mathrm{ml})$ and $\mathrm{CH}_{2} \mathrm{Cl}_{2}(25 \mathrm{ml})$. The $\mathrm{CH}_{2} \mathrm{Cl}_{2}$ extracts were washed with $\mathrm{H}_{2} \mathrm{O}$, dried, and concentrated to leave $9 \mathrm{a}$ ( $467 \mathrm{mg}$, $96 \%$ ) as a colorless solid, $\mathrm{mp} 144-148^{\circ} \mathrm{C}$. Recrystallization of the solid from benzene provided a pure sample as colorless prisms, $\mathrm{mp} 155-156^{\circ} \mathrm{C}$ (lit. ${ }^{7)} \mathrm{mp} 154.5-155.5^{\circ} \mathrm{C}$ ). This sample was identical (by mixture melting point test and comparison of the IR spectrum and TLC mobility) with authentic 9a. ${ }^{7)}$

ii) From 13: A solution of $13(573 \mathrm{mg}, 2 \mathrm{mmol})$ in $\mathrm{EtOH}(25 \mathrm{ml})$ containing $70 \%$ aqueous $\mathrm{HClO}_{4}(0.02 \mathrm{ml}, c a$. $0.2 \mathrm{mmol})$ was hydrogenated over $10 \% \mathrm{Pd}-\mathrm{C}(500 \mathrm{mg})$ at $17^{\circ} \mathrm{C}$ and atmospheric pressure for $1 \mathrm{~h}$. The reaction mixture was worked up in a manner similar to that described above under item (i), giving 9a (454 mg, 94\%), $\mathrm{mp} 149$ $150.5^{\circ} \mathrm{C}$. Recrystallization from benzene afforded a pure sample as colorless prisms, mp $153.5-154.5^{\circ} \mathrm{C}$. This sample was identical (by comparison of the IR spectrum and TLC mobility) with authentic 9a. ${ }^{7)}$

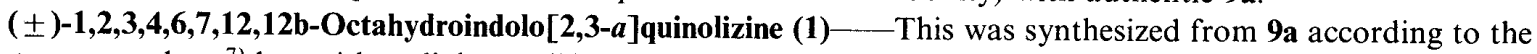
literature procedure, ${ }^{7)}$ but with a slight modification. A solution of $9 \mathrm{a}(484 \mathrm{mg}, 2 \mathrm{mmol})$ and $\mathrm{POCl}_{3}(2.5 \mathrm{ml})$ in dry benzene $(16 \mathrm{ml})$ was heated under reflux for $75 \mathrm{~min}$. The reaction mixture was concentrated in vacuo to leave a yellow solid, which was dissolved in $\mathrm{MeOH}(15 \mathrm{ml})$. The methanolic solution was stirred under ice-cooling, and $\mathrm{NaBH}_{4}$ $(379 \mathrm{mg}, 10 \mathrm{mmol})$ was added portionwise. After the mixture had been stirred at room temperature for $1 \mathrm{~h}$, acetone $(3 \mathrm{ml})$ was added. The resulting mixture was concentrated in vacuo to leave a yellowish solid, which was partitioned by extraction with a mixture of $\mathrm{H}_{2} \mathrm{O}(7 \mathrm{ml})$ and $\mathrm{CH}_{2} \mathrm{Cl}_{2}(15 \mathrm{ml})$. The $\mathrm{CH}_{2} \mathrm{Cl}_{2}$ extracts were washed with saturated aqueous $\mathrm{NaCl}$, dried, and concentrated to leave $1(431 \mathrm{mg}, 95 \%)$ as a yellowish solid, $\mathrm{mp} 148.5-149.5^{\circ} \mathrm{C}$. Recrystallization from hexane-benzene $(3: 1, \mathrm{v} / \mathrm{v})$ gave a pure sample as colorless prisms, $\mathrm{mp} 152.5-153.5^{\circ} \mathrm{C}\left(\mathrm{lit} .^{10 e}\right)$ mp $153-154^{\circ} \mathrm{C}$ ). This sample was identical (by mixture melting point test and comparisons of the IR and NMR spectra and TLC mobility) with authentic $1^{7)}$

( \pm )-trans-5-Ethyl-1-[2-(1 H-indol-3-yl)-2-oxoethyl]-2-oxo-4-piperidineacetic Acid Ethyl Ester (7b)-A mixture of $6^{12)}(2.72 \mathrm{~g}, 11 \mathrm{mmol})$, 3-(chloroacetyl)indole ${ }^{19)}(1.94 \mathrm{~g}, 10 \mathrm{mmol})$, and $\mathrm{KBr}(2.86 \mathrm{~g}, 24 \mathrm{mmol})$ in $\mathrm{HCONMe}_{2}$ $(12 \mathrm{ml})$ was stirred at $60^{\circ} \mathrm{C}$ for $38 \mathrm{~h}$. After addition of $\mathrm{H}_{2} \mathrm{O}(80 \mathrm{ml})$, the reaction mixture was extracted with AcOEt. The AcOEt extracts were washed with $\mathrm{H}_{2} \mathrm{O}$, dried, and concentrated to leave a brown oil. The oil was crystallized from AcOEt to yield $7 \mathbf{b}(1.50 \mathrm{~g})$ as slightly brownish prisms, $\mathrm{mp} 133.5-134.5^{\circ} \mathrm{C}$. The mother liquor of this crystallization was then concentrated in vacuo, and the residue was purified by means of column chromatography [silica gel, AcOEt-EtOH $(95: 5, \mathrm{v} / \mathrm{v})$ ] followed by recrystallization from AcOEt, giving a second crop (1.08 g) of $7 \mathbf{b}$. The total yield was $2.58 \mathrm{~g}[70 \%$ yield based on the 3-(chloroacetyl)indole used]. Further recrystallizations from AcOEt afforded an analytical sample as colorless prisms, $m p$ 135--136 ${ }^{\circ} \mathrm{C}$; MS $m / z: 370\left(\mathrm{M}^{+}\right)$; UV $\lambda_{\max }^{\mathrm{EtOH}} 241.5 \mathrm{~nm}(\varepsilon 15500)$, 260 (sh) (9200), $299(12700)$; IR $v_{\max }^{\text {Nujol }} \mathrm{cm}^{-1}: 3140(\mathrm{NH}), 1717$ (ester CO), 1658 (ArCO), 1610 (lactam CO); NMR $\left(\mathrm{CDCl}_{3}\right) \delta: 0.92\left(3 \mathrm{H}, \mathrm{t}, J=7 \mathrm{~Hz}, \mathrm{CCH}_{2} \mathrm{Me}\right), 1.26\left(3 \mathrm{H}, \mathrm{t}, J=7 \mathrm{~Hz}, \mathrm{OCH}_{2} \mathrm{Me}\right), 1.38-3.52\left(10 \mathrm{H}, \mathrm{m}_{,} \mathrm{CCH}_{2} \mathrm{Me} \mathrm{H}_{(3)}\right.$ 's, $\mathrm{H}_{(4)}, \mathrm{H}_{(5)}, \mathrm{H}_{(6)}$ 's, and $\left.\mathrm{CH}_{2} \mathrm{CO}_{2} \mathrm{Et}\right), 4.14\left(2 \mathrm{H}, \mathrm{q}, J=7 \mathrm{~Hz}, \mathrm{OCH}_{2} \mathrm{Me}\right), 4.35\left(2 \mathrm{H}, \mathrm{s}, \mathrm{COCH}_{2} \mathrm{~N}\right), 7.12-8.32(5 \mathrm{H}, \mathrm{m}$, aromatic protons), $10.64\left(1 \mathrm{H}\right.$, br s, NH). Anal. Calcd for $\mathrm{C}_{21} \mathrm{H}_{26} \mathrm{~N}_{2} \mathrm{O}_{4}: \mathrm{C}, 68.09 ; \mathrm{H}, 7.07 ; \mathrm{N}, 7.56$. Found: C, 68.25; H, 
$7.32 ; \mathrm{N}, 7.84$.

( \pm )-trans-5-Ethyl-1-[2-hydroxy-2-(1 H-indol-3-yl)ethyl]-2-oxo-4-piperidineacetic Acid Ethyl Ester (10b)-A solution of $7 \mathrm{~b}(2.22 \mathrm{~g}, 6 \mathrm{mmol})$ in EtOH $(200 \mathrm{ml})$ was stirred under ice-cooling and $\mathrm{NaBH}_{4}(5.68 \mathrm{~g}, 150 \mathrm{mmol})$ was added portionwise. After the mixture had been stirred at $22-25^{\circ} \mathrm{C}$ for $3 \mathrm{~h}$, acetone $(36 \mathrm{ml})$ was added under icecooling. The resulting mixture was stirred for a while and then concentrated in vacuo. The residue was treated with $\mathrm{H}_{2} \mathrm{O}(200 \mathrm{ml})$, and the aqueous mixture was neutralized with $10 \%$ aqueous $\mathrm{HCl}$ and extracted with $\mathrm{CH}_{2} \mathrm{Cl}_{2}$. The $\mathrm{CH}_{2} \mathrm{Cl}_{2}$ extracts were washed with $\mathrm{H}_{2} \mathrm{O}$, dried, and concentrated to leave a yellowish solid ( $\left.2.06 \mathrm{~g}\right)$. Recrystallization of the solid from AcOEt gave $10 \mathrm{~b}(1.56 \mathrm{~g}, 70 \%)$ as colorless needles, $\mathrm{mp} 120.5-122.5^{\circ} \mathrm{C}$, which were presumed to be a mixture of the two possible diastereomeric alcohols. Further recrystallizations from AcOEt furnished an analytical sample, but of unknown stereochemical purity, as colorless small needles, mp $122-123^{\circ} \mathrm{C} ; \mathrm{MS} m / z: 372\left(\mathrm{M}^{+}\right)$; UV $\lambda_{\max }^{\mathrm{EtOH}} 273.5 \mathrm{~nm}(\mathrm{sh})(\varepsilon 5700), 282(6100), 289.5(5200)$; IR $v_{\max }^{\mathrm{Nujol}} \mathrm{cm}^{-1}: 3260(\mathrm{NH}$ and OH), 1730 (ester CO), 1621 (lactam CO); NMR $\left(\mathrm{CDCl}_{3}\right) \delta: 0.48-0.88\left(3 \mathrm{H}, \mathrm{m}\right.$, diastereomeric $\mathrm{CCH}_{2} \mathrm{Me}$ 's), $1.22\left(3 \mathrm{H}, \mathrm{t}, J=7 \mathrm{~Hz}, \mathrm{OCH}_{2} \mathrm{Me}\right)$, $1.60-3.76\left(10 \mathrm{H}, \mathrm{m}, \mathrm{CCH}_{2} \mathrm{Me}, \mathrm{H}_{(3)}\right.$ 's, $\mathrm{H}_{(4)}, \mathrm{H}_{(5)}, \mathrm{H}_{(6)}$ 's, and $\left.\mathrm{CH}_{2} \mathrm{CO}_{2} \mathrm{Et}\right), 4.12\left(2 \mathrm{H}, \mathrm{q}, J=7 \mathrm{~Hz}, \mathrm{OC} \underline{\mathrm{H}}_{2} \mathrm{Me}\right), 4.00-4.32$ $(1 \mathrm{H}, \mathrm{br}, \mathrm{OH}), 5.16-5.40\left[1 \mathrm{H}, \mathrm{m}\right.$, diastereomeric $\mathrm{CH}(\mathrm{OH}) \mathrm{CH}_{2} \mathrm{~N}$ 's $], 6.90-7.76(5 \mathrm{H}, \mathrm{m}$, aromatic protons $), 8.60(1 \mathrm{H}$, brs, NH): Anal. Calcd for $\mathrm{C}_{21} \mathrm{H}_{28} \mathrm{~N}_{2} \mathrm{O}_{4}: \mathrm{C}, 67.72 ; \mathrm{H}, 7.58 ; \mathrm{N}, 7.52$. Found: C, 67.98; H, 7.67; N, 7.73.

( \pm )-trans-5-Ethyl-1-[2-(1 H-indol-3-yl)ethyl]-2-oxo-4-piperidineacetic Acid Ethyl Ester (9b)—A solution of 10b $(745 \mathrm{mg}, 2 \mathrm{mmol})$ in $\mathrm{EtOH}(25 \mathrm{ml})$ containing $70 \%$ aqueous $\mathrm{HClO}_{4}(0.02 \mathrm{ml}, \mathrm{ca} .0 .2 \mathrm{mmol})$ was hydrogenated over $10 \% \mathrm{Pd}-\mathrm{C}(600 \mathrm{mg})$ at $21-22^{\circ} \mathrm{C}$ and atmospheric pressure for $1 \mathrm{~h}$. The catalyst was removed by filtration, and the filtrate, after addition of $10 \%$ aqueous $\mathrm{Na}_{2} \mathrm{CO}_{3}$ ( 2 drops), was concentrated in vacuo. The residue was partitioned by extraction with a mixture of $\mathrm{H}_{2} \mathrm{O}(20 \mathrm{ml})$ and $\mathrm{CH}_{2} \mathrm{Cl}_{2}(80 \mathrm{ml})$. The $\mathrm{CH}_{2} \mathrm{Cl}_{2}$ extracts were washed with $\mathrm{H}_{2} \mathrm{O}$, dried, and concentrated to leave a reddish brown oil. Purification of the oil by column chromatography [silica gel (5 g), AcOEt] gave $9 \mathrm{~b}(529 \mathrm{mg}, 74 \%)$ as a slightly yellowish solid, $\mathrm{mp} 102.5-103.5^{\circ} \mathrm{C}$. Recrystallization from diisopropyl etherAcOEt $(2: 1, \mathrm{v} / \mathrm{v})$ yielded an analytical sample as colorless prisms, $\mathrm{mp} 107-108^{\circ} \mathrm{C}\left[\mathrm{lit} .{ }^{13 b)} \mathrm{mp} 108-110^{\circ} \mathrm{C}\right.$ (uncor.)]; MS $m / z: 356\left(\mathrm{M}^{+}\right)$; UV $\lambda_{\max }^{\mathrm{EtOH}} 276.5 \mathrm{~nm}(\mathrm{sh})(\varepsilon 5300), 284(5800), 292(5200) ; \mathrm{IR} v_{\max }^{\mathrm{Nujol}} \mathrm{cm}^{-1}: 3140,3100(\mathrm{NH}), 1722$ (ester CO), 1623 (lactam CO); NMR $\left(\mathrm{CDCl}_{3}\right) \delta: 0.74\left(3 \mathrm{H}, \mathrm{t}, J=7 \mathrm{~Hz}, \mathrm{CCH}_{2} \mathrm{Me}\right), 1.24\left(3 \mathrm{H}, \mathrm{t}, J=7 \mathrm{~Hz}, \mathrm{OCH}_{2} \mathrm{Me}\right)$, $1.80-3.28\left(12 \mathrm{H}, \mathrm{m}, \mathrm{CCH}_{2} \mathrm{Me}, \mathrm{ArC}_{2}, \mathrm{H}_{(3)}\right.$ ) $\mathrm{s}, \mathrm{H}_{(4)}, \mathrm{H}_{(5)}, \mathrm{H}_{(6)}$ 's, and $\left.\mathrm{CH}_{2} \mathrm{CO}_{2} \mathrm{Et}\right), 3.40-3.60\left(2 \mathrm{H}, \mathrm{m} \mathrm{ArCH}_{2} \mathrm{CH}_{2}\right)$, $4.14\left(2 \mathrm{H}, \mathrm{q}, J=7 \mathrm{~Hz}, \mathrm{OCH}_{2} \mathrm{Me}\right), 6.88-7.76(5 \mathrm{H}, \mathrm{m}$, aromatic protons $), 8.40(1 \mathrm{H}, \mathrm{brs}$, NH). Anal. Calcd for $\mathrm{C}_{21} \mathrm{H}_{28} \mathrm{~N}_{2} \mathrm{O}_{3}: \mathrm{C}, 70.76 ; \mathrm{H}, 7.92 ; \mathrm{N}, 7.86$. Found: $\mathrm{C}, 70.72 ; \mathrm{H}, 7.90 ; \mathrm{N}, 8.03$. This sample was identical (by mixture melting point test and comparison of the IR spectrum and TLC mobility) with authentic $9 \mathbf{b} .{ }^{13)}$

Acknowledgment We are grateful to Professor E. E. van Tamelen (Stanford University) for a valuable supply of a sample of the ( \pm )-trans-lactam ester $9 \mathbf{b}$, to Professor T. Hino (Chiba University) for a generous gift of the lactam 9a and the $( \pm)$-tetracyclic base 1 , and to Dr. M. Ohba (Kanazawa University) for clerical assistance in preparing the manuscript.

\section{References and Notes}

1) Paper XXIV in this series, T. Fujii and M. Ohba, Chem. Pharm. Bull., 36, 2665 (1988).

2) a) G. A. Cordell and J. E. Saxton, "The Alkaloids," Vol. 20, ed. by R. H. F. Manske and R. G. A. Rodrigo, Academic Press, New York, 1981, Chapter 1;b) Atta-ur-Rahman and A. Basha, "Biosynthesis of Indole Alkaloids," Clarendon Press, Oxford, 1983; c) C. Szántay, G. Blaskó, K. Honty, and G. Dörnyei, "The Alkaloids," Vol. 27, ed. By A. Brossi, Academic Press, New York, 1986, Chapter 2.

3) a) T. Fujii, S. Yoshifuji, and K. Yamada, Chem. Pharm. Bull., 26, 2071 (1978); b) T. Fujii, M. Ohba, K. Yoneyama, H. Kizu, and S. Yoshifuji, ibid., 34, 669 (1986), and references cited therein; c) T. Fujii, M. Ohba, K. Shimohata, and S. Yoshifuji, Heterocycles, 26, 2949 (1987); d) For a recent review, see T. Fujii, M. Ohba, and S. Yoshifuji, ibid., 27, 1009 (1988).

4) For reviews, see a) T. Fujii and M. Ohba, "The Alkaloids," Vol. 22, ed. by A. Brossi, Academic Press, New York, 1983, Chapter 1; b) T. Fujii, Yakugaku Zasshi, 103, 257 (1983).

5) A preliminary account of this work has been published: T. Fujii, S. Yosifuji, and H. Ito, Heterocycles, 7,149 (1977).

6) T. Oishi, M. Nagai, T. Onuma, H. Moriyama, K. Tsutae, M. Ochiai, and Y. Ban, Chem. Pharm. Bull., 17, 2306 (1969).

7) M. Nakagawa, M. Kiuchi, M. Obi, M. Tonozuka, K. Kobayashi, T. Hino, and Y. Ban, Chem. Pharm. Bull., 23, 304 (1975).

8) R. J. Sundberg, "The Chemistry of Indoles," Academic Press, New York, 1970, pp. 93-107.

9) a) S. R. Johns, J. A. Lamberton, and J. L. Occolowitz, Chem. Commun., 1966, 421; b) Idem, Aust. J. Chem., 19, 1951 (1966).

10) a) Ref. 10 in ref. 7; b) S. Yamada and T. Kunieda, Chem. Pharm. Bull., 15, 499 (1967); c) L. Novák and C. Szántay, Chem. Ber., 102, 3959 (1969); d) C. A. Scherer, C. A. Dorschel, J. M. Cook, and P. W. Le Quesne, J. Org. Chem., 37, 1083 (1972); e) G. W. Gribble, ibid., 37, 1833 (1972); f) H.-P. Husson, L. Chevolot, Y. Langlois, 
C. Thal, and P. Potier, J. Chem. Soc., Chem. Commun., 1972, 930; g) H. Akimoto, K. Okamura, M. Yui, T. Shioiri, M. Kuramoto, Y. Kikugawa, and S. Yamada, Chem. Pharm. Bull., 22, 2614 (1974); h) E. E. van Tamelen, J. Webber, G. P. Schiemenz, and W. Barker, Bioorg. Chem., 5, 283 (1976); i) S. Yamada, K. Murato, and T. Shioiri, Tetrahedron Lett., 1976, 1605; j) S. J. Martinez and J. A. Joule, Tetrahedron, 34, $3027(1978) ; k)$ E. Yamanaka, K. Nakayama, N. Yanagishima, K. Nagashima, M. Yamauchi, and S. Sakai, Chem. Pharm. Bull., 28, 2527 (1980); l) J. E. Johansen, B. D. Christie, and H. Rapoport, J. Org. Chem., 46, 4914 (1981); $m$ ) T. Fujii, M. Ohba, and N. Sasaki, Heterocycles, 22, 1805 (1984); $n$ ) A. I. Meyers, T. Sohda, and M. F. Loewe, J. Org. Chem., 51, 3108 (1986); o) G. W. Gribble and D. A. Johnson, Tetrahedron Lett., 28, 5259 (1987).

11) a) S. Sugasawa and T. Fujii, Pharm. Bull., 3, 47 (1955); b) T. Fujii, Chem. Pharm. Bull., 6, 591 (1958); c) T. Fujii, S. Yoshifuji, and M. Tai, ibid., 23, $2094(1975) ; d)$ T. Fujii, S. Yoshifuji, and M. Ohba, ibid., 26, 645 (1978); e) T. Fujii, H. Kogen, S. Yoshifuji, and K. Iga, ibid, 27, 1847 (1979); f) T. Date, K. Aoe, M. Ohba, and T. Fujii, Yakugaku Zasshi, 99, 865 (1979); g) T. Fujii, S. Yoshifuji, and K. Ikeda, Chem. Pharm. Bull., 27, 2841 (1979).

12) a) M. Uskoković, C. Reese, H. L. Lee, G. Grethe, and J. Gutzwiller, J. Am. Chem. Soc., 93, 5902 (1971); b) J. Gutzwiller, G. Pizzolato, and M. R. Uskoković, Helv. Chim. Acta, 64, 1663 (1981); c) T. Fujii and S. Yoshifuji, Chem. Pharm. Bull., 27, 1486 (1979).

13) a) E. E. van Tamelen and J. B. Hester, Jr., J. Am. Chem. Soc., 81, 3805 (1959); b) Idem, ibid., 91, 7342 (1969).

14) J. A. Weisbach, J. L. Kirkpatrick, K. R. Williams, E. L. Anderson, N. C. Yim, and B. Douglas, Tetrahedron Lett., 1965, 3457 .

15) C. Szántay and M. Bárczai-Beke, Chem. Ber., 102, 3963 (1969).

16) J. P. Kutney and R. T. Brown, Tetrahedron, 22, 321 (1966).

17) T. R. Govindachari and S. Rajeswari, Indian J. Chem., 22B, 531 (1983).

18) T. Fujii, M. Ohba, T. Tachinami, H. Miyajima, M. Koch, and E. Seguin, Heterocycles, 24, 1215 (1986).

19) a) J. Bergman, J. Heterocycl. Chem., 7, 1071 (1970); b) J. Bergman, J.-E. Bäckvall, and J.-O. Lindström, Tetrahedron, 29, 971 (1973). 